M. MAETANi, N. KAto, V. A. P. JABOR, F. A. CAlil, M. C. NONATO, C. A. SCHERER, S. L. SCHREIBER* (HARVARD UNIVERSITY, BROAD INSTITUTE, AND HOWARD HUGHES MEDICAL INSTITUTE, CAMBRIDGE, USA; UNIVERSITY OF SÃO PAULO, BRAZIL) Discovery of Antimalarial Azetidine-2-carbonitriles that Inhibit P. falciparum Dihydroorotate Dehydrogenase ACS Med. Chem. Lett. 2017, 8, 438-442.

\section{Synthesis of Dihydroorotate Dehydrogenase Inhibitor BRD9185}

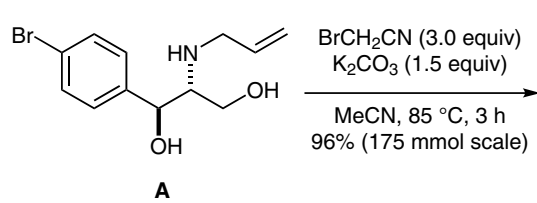<smiles>C=CCN(CCO)C(CO)C(O)c1ccc(Br)cc1</smiles>

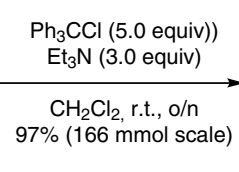<smiles>C=CCN(CC#N)[C@@H](COCCCCCCC)C(O)c1ccc(Br)cc1</smiles>

B

c

$$
\begin{array}{r}
\mathrm{SOCl}_{2}(214 \mathrm{~mm}) \\
\text { py (5.0 equiv) } \\
\mathrm{CH}_{2} \mathrm{Cl}_{2}, 0^{\circ} \mathrm{C}, 25 \mathrm{~min}
\end{array}
$$
$66 \%(160 \mathrm{mmol}$ scale $)$

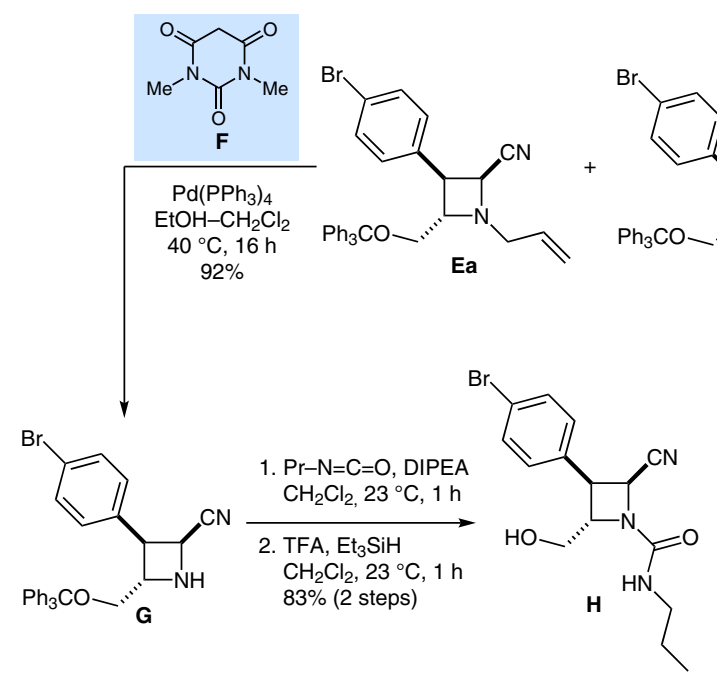

\section{Category}

Synthesis of Natural

Products and

Potential Drugs

\section{Key words}

BRD9185

dihydroorotate dehydrogenase

azetidine-2carbonitriles

4-exo-tet cyclization
Significance: Dihydroorotate dehydrogenase $(\mathrm{DHODH})$ is necessary for pyrimidine biosynthesis in protozoan parasites of the genus Plasmodium, the causative agents of malaria. BRD9185 is a $\mathrm{DHODH}$ inhibitor that has in vitro activity against multidrug-resistant blood-stage parasites $\left(\mathrm{EC}_{50}=\right.$ $0.016 \mu \mathrm{M})$ and is curative after just three doses in a $P$. berghei mouse model. BRD9185 has a long half-life (15 h) and low clearance in mice.
Comment: The key step in the synthesis depicted was the construction of the azetidine-2-carbonitrile core by a 4-exo-tet cyclization of the anion derived from $\mathbf{D}$. The stereochemistry of the cyclization depended on the base. Treatment of $\mathbf{D}$ with LiHMDS at $-50^{\circ} \mathrm{C}$ provided the products Ea and $\mathbf{E b}$ in a ratio of approximately $15: 1$ as a separable mixture. Alternatively, exposure of $\mathbf{D}$ to KHMDS at $-78^{\circ} \mathrm{C}$ gave nearly exclusively $\mathbf{E b}(\mathbf{E a} /$ $\mathbf{E b} \approx 1: 20$ ). The conversion of $\mathbf{A}$ into $\mathbf{E}$ is described in a preceding paper: J. T. Lowe et al. J. Org. Chem. 2012, 77, 7187.

SYNFACTS Contributors: Philip Kocienski 